\title{
Diversity and Paleoenvironmental Signature of Benthic Foraminifera of St. Martin's Island, Bangladesh
}

\author{
Tamanna Meheran Shemuㄹ and Subrota Kumar Saha² \\ ${ }^{1}$ Barapukuria Coal Mining Company Limited, Parbatipur, Dinajpur, Bangladesh \\ ${ }^{2}$ Department of Geology, University of Dhaka, Dhaka 1000, Bangladesh \\ Manuscript received: 11 November 2020; accepted for publication: 17 February 2021
}

\begin{abstract}
The present research is concerned with the investigations of the paleoenvironment of the benthic foraminifera and their diversity in St. Martin's Island, Bangladesh. About 300 specimens of foraminifera were collected from three sampling sites of the island. Among them 44 species, 39 genera and 25 families were identified which were mostly benthic in origin. Astrorhiza, Elphidium, Cyclammina, Cibicides, and Eponoide were the most abundant genera all over the island based on their relative abundance and frequency of occurrence. Among the three sections, Uttar Para can be designated as Astrorhiza- Elphidium assemblage zone, Maddhya Para as Astrorhiza-Elphidium assemblage zone and Dakkhin para as Astrorhiza-Cibicides assemblage zone. The relative abundance chart of foraminifera and its correlation with the Saraswati and Srinivasan (2016) model diagram indicates that the paleoenvironment signature of the island belongs to the inner shelf to the middle shelf region. The plot of shell-type ratios on Murray's ternary diagram also suggests the same paleoenvironment. Gibson's index of oceanity was 2\% which indicates a shelf environment where the diversity of benthic foraminifera is high. Murray's index of diversity for all three sections was above the range $\mathrm{V}$, which indicates the normal salinity of the ocean.
\end{abstract}

Keywords: Paleoenvironmental signature, Foraminifera, Ecological tolerances, St. Martin's Island, Bay of Bengal

\section{INTRODUCTION}

Diversity of foraminifera react quickly to natural and anthropogenic changes and the changes are preserved in their test compositions, morphology, and wall structures (Schafer, 2000). Because of the higher preservation potential of their shells in marine sediments, benthic foraminiferal taxa are widely used for bio-monitoring tools (Bilyard, 1987). The shelf region of the Bay of Bengal encompasses a variety of coastal marine environments viz. delta, estuaries, and continental shelf which are regions of highly fluctuating environmental conditions. The benthic foraminiferal species and their distribution are mainly influenced or controlled by several parameters such as depth, nature of substrate, nutrient input, physicochemical parameters of the bottom water, and hydrodynamic factors.

Several studies were carried out on recent foraminifera during the late $50 \mathrm{~s}$ and $60 \mathrm{~s}$ of the last century in the Bay of Bengal. Schwager (1866) studied the Foraminifera in the Bay of Bengal for

Corresponding author: Subrota Kumar Saha

Email: sks@du.ac.bd

DOI: https://doi.org/10.3329/dujees.v9i1.54858 the first time. The distribution of shelf benthic foraminifera in the Bay of Bengal has been investigated in various regional studies on various aspects such as ecology and distribution of foraminifera, foraminiferal diversity, changes in intertidal foraminifera due to oceanic disturbances, etc. (Ganapati, 1958; Setty 1978; Rao and Vedantam, 1968; Nigam and Khare, 1999; Nigam et al., 2007). Among them foraminiferal research from Indian coastal water received much popularity and attention (Ganpati, 1958; Rocha, 1964; Bhalla, 1967 and Bhatia, 1956). Because of oceanographic similarities, foraminiferal studies carried out in the Indian Ocean can be considered as a framework database for a similar kind of research in the Bay of Bengal. The Recent foraminifera from the shelf of the Bay of Bengal, East Coast of India, and estuaries have been investigated by earlier researchers (Talib and Farroqui, 2007; Nisha and Singh, 2012; Kathal and Singh 2010). These studies demonstrate significant spatial differences in the composition of shelf faunas.

Sifat and Saha $(2018,2019)$ studied intertidal foraminifera from the eastern coastal margin of Bangladesh and established three assemblage zones by recording 150 species to reconstruct the Holocene sea-level change. Tushar et al. (2019) assessed the indicative values of salt-marsh foraminifera to reconstruct paleoenvironmental signature based on 
taxonomic, statistical, and morphological parameters from the recorded species from Cox's Bazar to the Teknaf area.

No such detailed micropaleontological studies have been carried out in St. Martin's Island, Bangladesh. The aim of the study is to predict the diversity and paleoenvironment of benthic foraminifera in St. Martin's island based on taxonomic position, test morphology, test composition, relative abundance, and assemblage zones of benthic foraminifera.

\section{MATERIALS AND METHODS}

St. Martin's Island is located in the northeast margin of the Bay of Bengal lies between latitude $20^{\circ} 34^{\prime}$ and $20^{\circ} 39^{\prime} \mathrm{N}$, and longitude $92^{\circ} 18^{\prime}$ and $92^{\circ} 21^{\prime} \mathrm{E}$. The island is $6.75 \mathrm{~km}$ long and is aligned to NNW and SSE directions. The Island is almost flat with an average height of $2.5 \mathrm{~m}$ above mean sea level (MSL). Since, it is a small island, the exposed surface area changes due to the high and low tides, rising to a maximum of $6.5 \mathrm{~m}$ (Thomson and Islam, 2010).

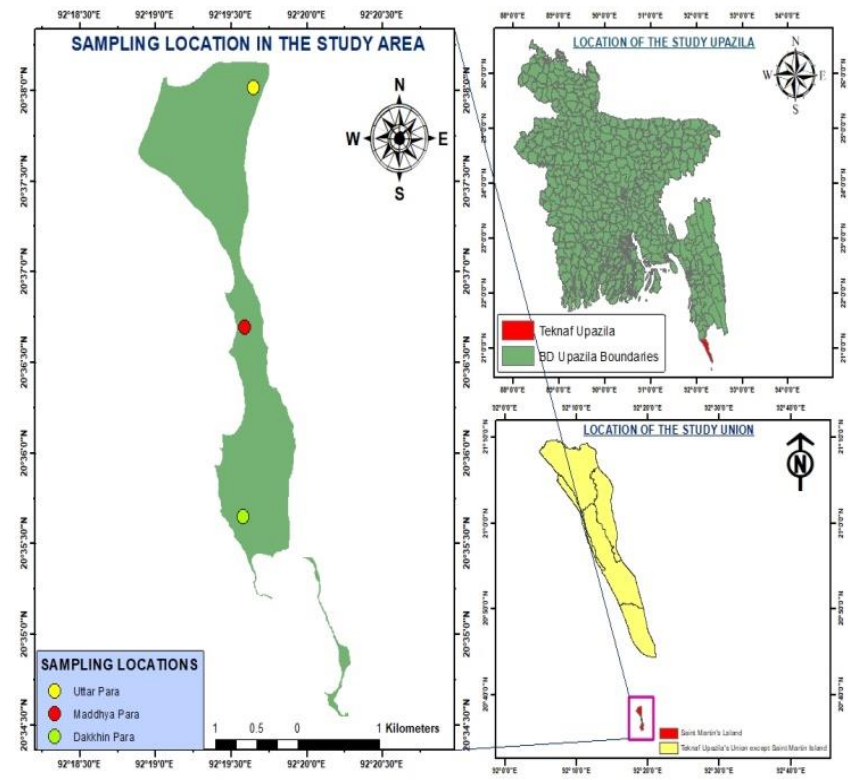

Figure 1: Location map of St. Martin's Island highlighting sampling location

The stratigraphic succession of the island gave an insight into the sampling and sampled material (Monsur, 2020).
Table 1: Stratigraphic succession of St Martin's Island (after Monsur, 2020)

\begin{tabular}{|c|c|c|}
\hline Epochs & Units & Lithology \\
\hline \multirow[t]{3}{*}{ Holocene } & $\begin{array}{l}\text { Beach } \\
\text { sediments }\end{array}$ & $\begin{array}{l}\text { Beach sediments are } \\
\text { represented by dune and beach } \\
\text { sand, coquina shells, dead and } \\
\text { recent corals, calcareous } \\
\text { concretions, boulders and } \\
\text { conglomerates. }\end{array}$ \\
\hline & Old coquina & $\begin{array}{l}\text { Coquina or soft limestone } \\
\text { represented by corals, } \\
\text { foraminifera and Mollusk } \\
\text { shells. It covers the surface of } \\
\text { the island and made a cliff } \\
\text { along the eastern side of } \\
\text { Dakshin Para coast. }\end{array}$ \\
\hline & $\begin{array}{l}\text { Coralline } \\
\text { limestone } \\
\text {------------- }\end{array}$ & 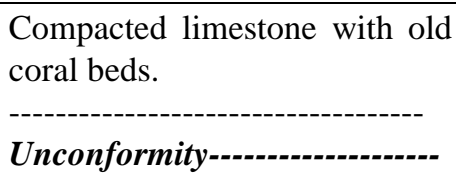 \\
\hline Miocene & $\begin{array}{l}\text { Shale and } \\
\text { sandstones }\end{array}$ & $\begin{array}{l}\text { Thinly laminated shale, } \\
\text { sandstone and conglomerate } \\
\text { bed. }\end{array}$ \\
\hline
\end{tabular}

In the present research both surface as well as subsurface samples from Holocene sediments regarding Beach sediments, Old Coquina Bed and Coralline Limestone were collected with the help of auger drilling (Table 1) and put into individual polybag labelled with their respective locations and depth. After collection, samples were washed and dried in an oven at $100^{\circ} \mathrm{C}$ temperature for 30 minutes. $100 \mathrm{gm}$ of samples were weighted from each location and placed onto a standard-sized sieve. Individuals forams were picked from $>125 \mu \mathrm{m}$ fraction, mounted, and identified (Loeblich and Tappan, 1964; Cushman, 1993) under a binocular microscope.

Table 2: Sampling location and depth in the study area.

\begin{tabular}{|c|c|c|c|c|}
\hline Sample ID & $\begin{array}{l}\text { Location } \\
\text { Name }\end{array}$ & Latitude & Longitude & $\begin{array}{l}\text { Depth } \\
\text { (m) }\end{array}$ \\
\hline SM-01 & \multirow[t]{2}{*}{$\begin{array}{l}\text { Dakkhin } \\
\text { Para }\end{array}$} & \multirow[t]{2}{*}{$\begin{array}{l}20^{0} \quad 35^{\prime} \\
38.9^{\prime \prime}\end{array}$} & \multirow[t]{2}{*}{$\begin{array}{l}92^{0} \quad 19^{\prime} \\
34.9^{\prime \prime}\end{array}$} & 1.5 \\
\hline SM-02 & & & & 2.5 \\
\hline SM-03 & \multirow{3}{*}{ Uttar Para } & \multirow[t]{3}{*}{$\begin{array}{cc}20^{0} & 38^{\prime} \\
01 ” & \end{array}$} & \multirow[t]{3}{*}{$\begin{array}{ll}92^{0} & 19^{\prime} \\
39.0^{\prime \prime} & \end{array}$} & 0.06 \\
\hline SM-04 & & & & 0.5 \\
\hline SM-05 & & & & 1.0 \\
\hline SM-06 & \multirow{3}{*}{$\begin{array}{l}\text { Madhya } \\
\text { Para }\end{array}$} & \multirow{3}{*}{$\begin{array}{ll}20^{0} & 36^{\prime} \\
41.6^{\prime \prime} & \end{array}$} & \multirow{3}{*}{$\begin{array}{l}92^{0} \quad 19^{\prime} \\
35.3^{\prime \prime}\end{array}$} & 0.5 \\
\hline SM-07 & & & & 1.0 \\
\hline SM-08 & & & & 1.5 \\
\hline
\end{tabular}


In the investigations of paleoenvironment assessment, various attributes were used such as relative abundance, test morphology, wall composition, planktonic to benthic ratio, functional group. Based on the mentioned attributes various statistical calculations (Paleontological Statistics, PAST software, Version 2.17) were used and various Schematic diagrams were produced and correlated with some world standard model diagrams. Based on the model diagrams various Foraminiferal assemblage zones were identified and their depositional environments were indicated. By calculating the planktonic to benthic ratios, the average paleodepth at which they lived were calculated.

\section{RESULT AND DISCUSSION}

\section{Establishment of Assemblage Zone}

In this study, about 300 specimens including 294 benthic and 6 planktonic foraminifera were investigated (Table 3). Among them, 44 species, 39 genera and 25 families were identified. Best represented microphotographs of 39 genera are presented in the plates (Plate 1-2). Based on the frequency of occurrence of a single species in samples from a particular location, the relative abundance of each species is prepared for each of the three locations. The assemblage zones are identified based on the most abundant species.

In Uttar Para section, 94 specimens were collected belonging to 22 genera. The relative percentage of each genus has been calculated based on their frequency.

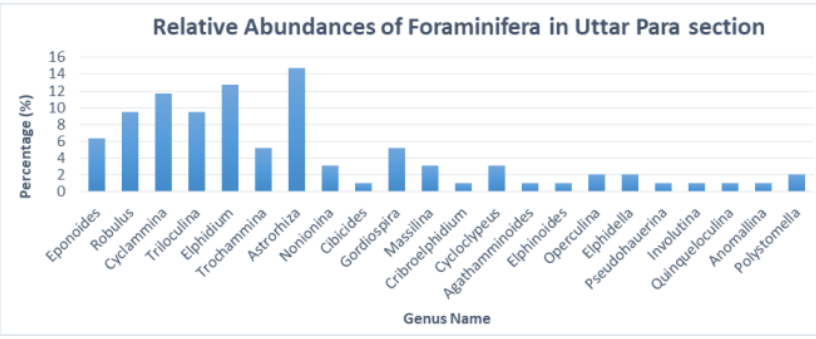

Figure 2: Relative abundances of foraminifera in Uttar Para section.

The obtained result shows that Astrorhiza has the highest frequency of occurrences (14.74\%). Other abundant species are Elphidium (12.77\%), Cycl ammina (11.7\%), Triloculina (9.47\%) and Robulus $(9.47 \%)$. Based on the relative frequency of occurrences, Uttar Para is designated as AstrorhizaElphidium assemblage zone (Fig. 2).

In Maddhya Para, 130 foraminifera specimens were counted belonging to 25 genera.

Relative abundances of foraminifera in Maddhya Para section.

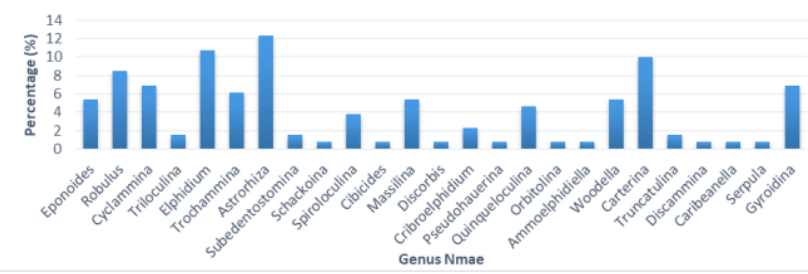

Figure 3: Relative abundances of foraminifera in Maddhya Para section

The result shows that Astrorhiza (12.3\%) has the highest frequency of occurrence. The second highest frequency of occurrence is Elphidium (10.77\%). Other abundant species are Carterina (10\%) and Robulus $(8.46 \%)$. So, Maddhya Para region is designated as Astrorhiza-Elphidium assemblage zone (Fig. 3).

In Dakkhin para section, 75 specimens of foraminifera were counted belonging to 18 genera.

Relative Abundance of Foraminifera in Dakkhin para

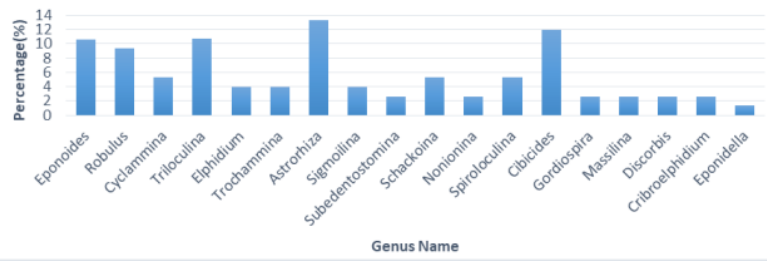

Figure 4: Relative abundances of foraminifera in Dakkhin Para section.

The result shows that the highest frequency of occurrences has Astrorhiza (13.33\%). Other abundant species are Cibicides (12\%), Eponoides (10.6\%), Robulus $(9.33 \%)$. So, this section is designated as the Astrorhiza-Cibicides assemblage zone (Fig. 4).

Foraminiferal genera occur in different depth zones and their abundances changes from one depth zone to the next. Variation in assemblage zones in different depths occurs due to the changes of one or more environmental variables such as light, organic flux, oxygen etc. So, the occurrence of any one of the species within any assemblage indicates a corresponding ocean water zone as their paleoenvironment. 


\section{Paleobathymetry Investigations Based on Relative Abundance}

Foraminiferal genera occur in different depth zones and their abundances changes from one depth zone to the next. Variation in assemblage zones in different depths occurs due to the changes of one or more environmental variables such as light, organic flux, oxygen etc. So, the occurrence of any one of the species within any assemblage indicates a corresponding ocean water zone as a paleoenvironment.

To interpret the Paleoenvironment of St. Martin's Island, a relative abundance chart of species has been constructed and compared with the world standard diagram.

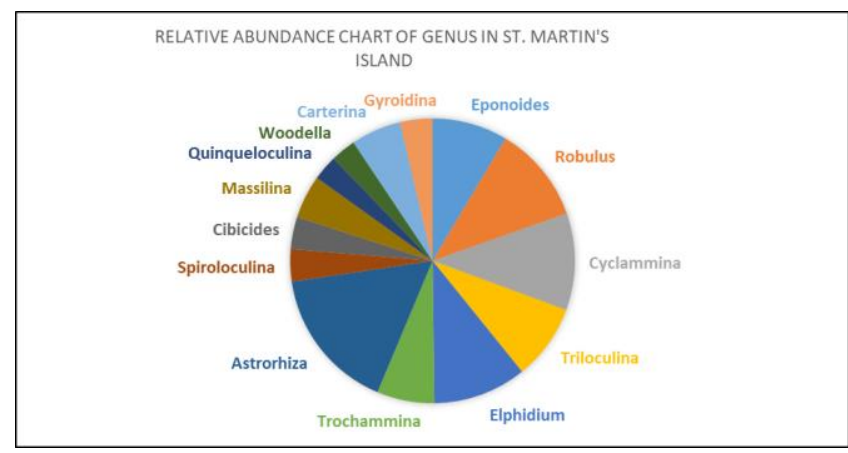

Figure 5: Relative abundance pie chart of foraminifera in St. Martin's Island.

From the chart, it is clear that Astrorhiza, Elphidium, Cyclammina, Robulus and Eponoides are the top five most abundant genera all over the island.

To interpret the paleoenvironment of these genera the diagram of Saraswati and Srinivasan (2016) presented a simplified depth distribution of the foraminiferal genera in marginal marine, continental shelf, bathyal and abyssal plain environment.

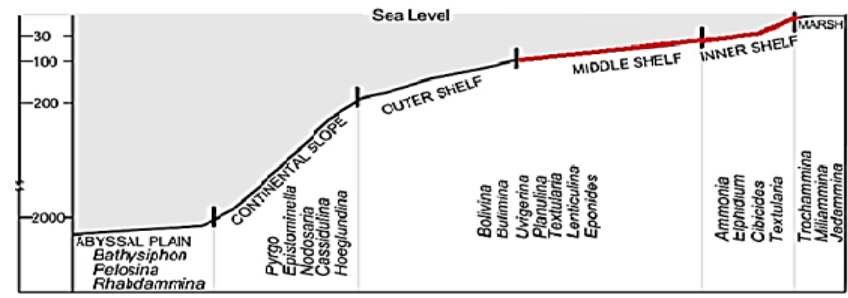

Figure 6: Model diagram of diagnostic forams highlighting the paleoenvironment (modified after Saraswati and Srinivasan, 2016).

After correlating the Relative Abundance Chart with Saraswati and Srinivasan, (2016) model diagram, the interpreted paleoenvironment of the genera is an inner shelf to middle shelf at a water depth between 30-100m.

\section{Investigations of Paleoenvironment based on Index of Oceanity}

The Index of Oceanity of a foraminiferal population (Gibson, 1989) is the quantitative relationship between the number of planktonic and the total number of individuals (benthic + planktonic) in the sediment. The total of $(\mathrm{P}+\mathrm{B})$ should be between 100 and 300 .

Index of Oceanity, $\mathrm{i}=\mathrm{P} /(\mathrm{P}+\mathrm{B})$; $\mathrm{P}$ for Planktonic foraminifera and $\mathrm{B}$ for Benthic foraminifera.

Optimum productivity for planktonic foraminifers is in marine waters far from a coast. Benthic foraminifers proliferate on continental platforms. So, the index of oceanity permits the evaluation of bathymetry and consequently the several environments encountered in a profile embracing the tracts from the continental platform to the abyssal domain.

Studies carried out in different regions of the Globe show that a proportion of $50 \%$ planktonic foraminifera occurs at a depth between 100 and 200 meters. It equates with the outer zone of the continental platform (circalittoral stage). The proportion increases very rapidly at the outer limit of the platform, and at depths greater than $200 \mathrm{~m}$ the index of oceanity is more than 80\%. (Gibson, 1989). In the present study, the following data was accumulated:

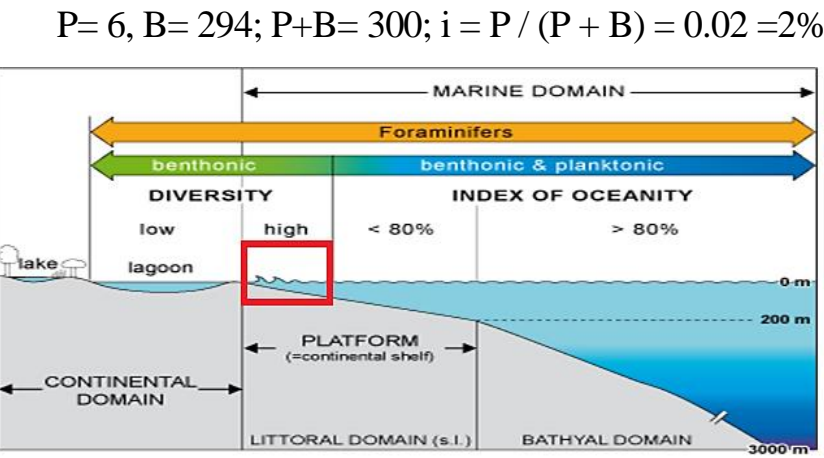

Figure 7: Index of oceanity based on diversity of Foraminifera (after Gibson, 1989).

From Gibson's diagram, the index of oceanity obtained in the present research $2 \%$ which is less than $80 \%$ and the benthic diversity is higher than planktonic diversity. According to Gibson (1989), the paleoenvironment of foraminifera was in the 
continental shelf region where the water depth is less than $200 \mathrm{~m}$ with the littoral domain.

\section{Index of Diversity and strategies for living}

Diversity refers to the number of species. Although depth is only one of a number of variables controlling the foraminiferal population, abundance and diversity are typically highest in deep water. High abundance associated with low diversity often indicates some form of environmental stress, such as temperature, salinity, oxicity, or toxicity (Jones, 2014). In practice, the index values are calculated by counting the number of individuals as abscissa and the number of species as an ordinate (indices in Roman numerals). Continental seas of normal salinity are thus distinguished quite clearly from hypo- and hypersaline lagoons and swamps, the distinction being the line of the diversity of index $\mathrm{V}$.

In this study, the number of species and number of specimens were counted for the three sites of the St. Martin's Island (Table 3) and their diversity index was calculated on the basis of Murray's Index of Diversity, 1991 (Fig 8).

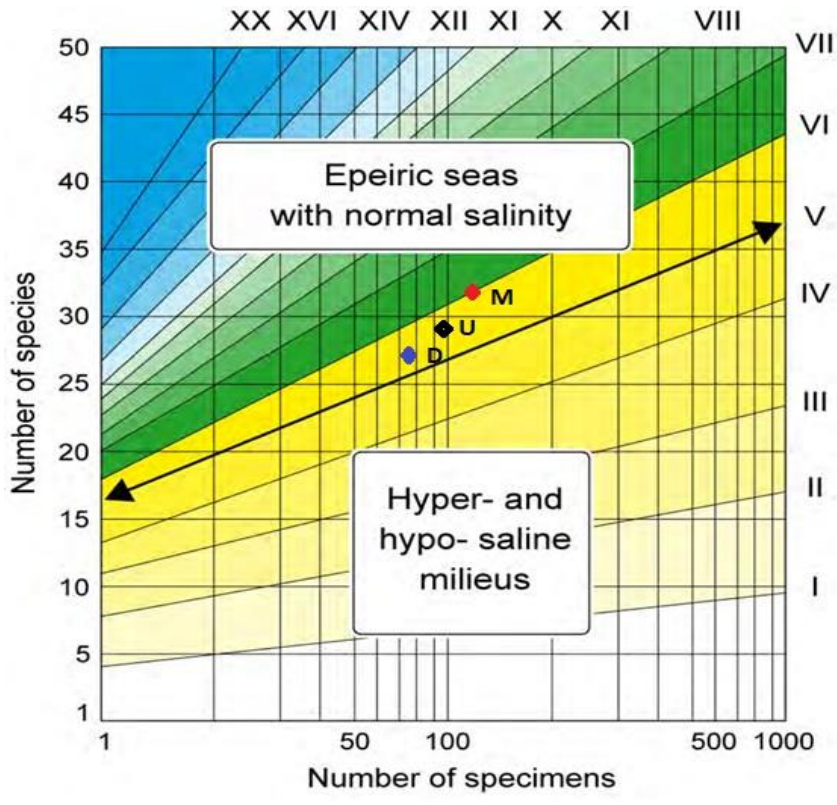

Figure 8: Index of diversity plot. Here, U=Uttar Para section, M=Maddhya Para section, $\mathrm{D}=$ Dakkhin Para section. Index of diversity $>\mathrm{V}$ distinguish the eperic seas with normal salinity, those with diversity $<\mathrm{V}$, the hyper-and hypo-saline milieus (Murray, 1991)

After Murray (1991) the index of diversity in St. Martin's island is $>V$ which indicates continental sea with normal salinity.

\section{CONCLUSIONS}

The diversity of foraminifera is directly related to ecological factors such as water salinity, bathymetry, sedimentary environment, substrate, temperature, etc. plays a vital role in their diversity and abundance. Having broad ecological tolerances, they are distributed throughout all marine realm, from marginal marine to deep bathyal environment. Foraminiferal abundance and diversity are the important factors to study their paleoenvironment of living, paleoecology, and paleobathymetry. Moreover, anthropogenic factors control the calcium carbonate availability and $\mathrm{pH}$ level of the water which also determine their diversity and dominance of certain taxa. The abundance of foraminifera in St. Martin's Island is mainly benthic in origin. The most abundant genus is Astrorhiza which is found in every sampling site of the island with a higher frequency of occurrences. The abundance of other genus indicates that their distribution varies from marginal marine to deep environment. The index of oceanity for the foraminiferal population is $2 \%$ which also concludes that they are mostly benthic and proliferate in water depth less than $200 \mathrm{~m}$ (shallow marine environment). The diversity indices of the three sampling sites are $>\mathrm{V}$ which indicates the normal salinity of the ocean. The findings of this study can be incorporated with the future ecological and biostratigraphic study of the island.

\section{REFERENCES}

Bhalla, S. N. (1967). Recent Foraminifera from the Vishakhapottom beach sands and its relation to the known foram geographical provinces in the Indian Ocean. Bull.Nat.inst.Sci.India 38:376-392.

Bhatia, S. B. (1956). Recent foraminifera from the shore sands of western India. Foram.Res. 7:15-24.

Bilyard, G.R. (1987). The value of benthic infauna in marine pollution monitoring studies. Marine Pollution Bulletin: 581-585. 
Cushman, J. A. (1993). Foraminifera: Their classification and economic Use. Cambridge: Harvard University Press.

Ganpati, P. N. (1958). "Report on Foraminifera in Bottom sediments in the Bay of Bengal off the east coast of India. Andhra.Univ.Mem.Oceanography. 2:100-127.

Gibson T.G. (1989). Planktonic benthonic foraminiferal ratios: modern patterns and Tertiary applicability. Marine Micropaleontology, Amsterdam, 15 (1-2): 29-52.

Kathal, P.K. and Singh, V.K. (2010). First report on some recent benthic foraminifera from the East coast of India. Journal of the Geological Society of India, 76:69-74.

Jones, R.W. (2014). Foraminifera and their application. Cambridge University Press, New York.

Loeblich, A. and Tappan, H. (1964). Treatise on Invertebrate Paleontology, Part C, Protista 2, Sarcodina, chiefly 'Thecamoebians' and Foraminiferida.; Lawrence, KS; University of Kansas Press.

Monsur, M.H. (2020). Quaternary Geology of Bangladesh. Rehana Akhter, 88 Tejkunipara, Tejgaon, Dhaka 1215.

Murray, J.W. (1991). Ecology and Palaeoecology of Benthic Foraminifera. Harlow; Longman Scientific \& Technical.

Nigam, R. and Khare, N. (1999). Spatial and temporal distribution of foraminifera in sediments off the central west coast of India and use of their test morphologies for the reconstruction of paleomonsoonal precipitation. Micropaleontology, 45:285-303. https://doi.org/10.2307/1486138

Nigam. R., Mazumdar. A., Henriques, P.J., Saraswati, R. (2007). Benthic foraminifera as proxy for oxygendepleted conditions off the central west coast of India. Journal of the Geological Society of India 70:10471054.

Nisha, N.R. and Singh, A.D. (2012). Benthic foraminiferal biofacies on the shelf and upper continental slope off North Kerala (Southwest India). Journal of the Geological Society of India, 80:783-801.
Rao, M.S. and Vedantam, D. (1968). Distribution of foraminifera in Vishakhapatnam, Bay of Bengal. Bulletin National Institute of Science India, 38:491-501

Rocha, A.T. (1964). Contribution for the study of Foraminifera from sands of Diu, Gogha, and simbor. Garcia de Orta(Lisboa) 12: 407-420.

Saraswati, P. K. and Srinivasan, M. S. (2016). Micropaleontology principles and applications. London. Springer international publishing.

Schwager, C. (1866). Fossile Foraminiferen von Kar Nikobar. Reise der Österreichischen Fregatte Novara um die Erde in den Jahren 1857, 1858, 1859 unter den Befehren des Commodore B. von Wüllerstorf - Urbair, Geologischer Theil, 2:187-268.

Schafer, C.T. (2000). Monitoring nearshore marine environments using benthic foraminifera: some protocols and pitfalls. Micropaleontology 46:161-169.

Setty, M.G.A.P. (1978). Shelf edge regime and foraminifera off Pondicherry, Bay of Bengal. Indian Journal of Marine Sciences, 7:302-304.

Sifat, H. F. and Saha, S.K. (2018). Systematics of Benthic Foraminifera and its paleoenvironment considerations from the beach sands of Cox's Bazaar, Bangladesh, DU Jour of Earth and Env Sci, 6 \& 7:85103.

Sifat, H. F. and Saha, S. K. (2019). Using the Benthic Foraminifera as an Indicator of Holocene Sea Level Rise from Eastern Coastal Margin of Bangladesh, Journal of Climate Change, 5 (1): 9-18; DOI: 10.3233/JCC190002.

Talib, A. and Farroqui, M.Y. (2007). Distribution of recent foraminifera in the littoral sediments of Dwarka, Saurashtra coast, Gujarat. Journal of the Palaeontological Society of India, 52(1):17-25.

Thompson, P. M. and Islam, M.A. (2010). Environmental Profiles of St. Martin Island. Coastal and Wetlands Biodiversity Management Project A Partnership between Department of Environment Ministry of Environment and Forest and UNDP, Bangladesh.

Tushar, M.A.N., Saha, S. K. and Monsur, M. H. (2019). Paleoenvironmental significance of Foraminiferal assemblage from the Cox's BazarTeknaf coast. Dhaka University Journal of Earth and Environmental Sciences, 6 and 7: 57-69. 